Vol. 15 (2006): 43-60.

\title{
Sowing time affects the abundance of pests and weeds in winter rye
}

\author{
Erja Huusela-Veistola, Heikki Jalli, Jukka Salonen, Katri Pahkala \\ MTT Agrifood Research Finland, Plant Production Research, FI-31600 Jokioinen, Finland, \\ e-mail:erja.huusela-veistola@mtt.fi
}

Antti Laine

MTT Agrifood Research Finland, Plant Production Research, Toivonlinnantie 518, FI-21500 Piikkiö, Finland

\begin{abstract}
Selection of an appropriate sowing time for some winter rye (Secale cereale) cultivars could reduce the need for crop protection measures. In this study the occurrence and status of pests and weeds in relation to sowing time and growth habit of winter rye was studied in southern Finland. This was done using three sowing times and four rye varieties in field trials conducted at three locations in 1999-2001. The early sown rye was severely affected by pests (Oscinella frit, Mayetiola destructor) and weeds, whereas postponing sowing for two weeks after the recommended sowing time in late August resulted in considerably less damage and the optimal establishment of crop stands. The German hybrid varieties Picasso and Esprit produced more tillers $\mathrm{m}^{-2}$ in autumn than the Finnish varieties Anna and Bor 7068. However, the number of pests and weeds did not differ among rye varieties. Late sowing of rye should be considered to minimize the need for plant protection. If rye is sown at the recommended time it may still require insecticide treatments promptly in the autumn whereas herbicide treatment need not be determined until spring, after recording the winter mortality of weeds.
\end{abstract}

Key words: Oscinella frit, Mayetiola destructor, weeds, crop establishment, winter rye, Secale cereale, Finland

\section{Introduction}

Winter rye (Secale cereale L.) is a traditional cereal crop grown in Finland mainly for bread making. The growing area has decreased from 122000 hectares (14\% of total cereal area) in 1950 (Muku- la and Rantanen 1989) to 44600 ha (2.5\% of total cereal area) in 2000 and to 30700 ha in 2003 (Yearbook of farm statistics 2003). The main factors that have contributed to the decline in rye cultivation are rainy autumns, which prevent sowing, and long-strawed varieties unsuitable for modern harvesting technology. Furthermore, winter rye 
Huusela-Veistola, E. et al. Sowing time affects abundance of pests and weeds in rye

production is generally uneconomic compared with other field cereals: winter rye's marginal contribution was only $78 \%$ that of spring wheat and $86 \%$ that of winter wheat in south-western Finland (Laine 2005). The main reasons for poor profitability are low yields and high variable costs.

In 1999, the research programme "Intensifying rye breeding and cultivation in the Nordic regions" was launched in order to guarantee the continuation of Finnish rye production. The programme focused on introducing new varieties with specified crop management methods. Cultivated rye varieties changed from native landraces to Finnish population varieties from the 1930s to the 1960 s (Paatela 1953, Pessi 1965). Currently, rye genotypes from central Europe cover more than 25 percent of the rye cropping area in Finland (Year book of farm statistics 2004).

Overwintering of modern varieties, their reactions to pests and diseases, and the occurrence of weeds in rye fields can depend on sowing time. The recommended sowing dates have changed over time, reflecting the introduction of new varieties and options for chemical control. Sowing date trials with winter rye from 1933-1957 indicated that earlier sowings in mid August were often severely damaged by larvae of frit fly (Oscinella frit L.) and leaf rust (Puccinia recondita Roberge ex Desmaz.). Furthermore, pink snow mould (Microdochium nivale (Fr.) Samuels \& I.C. Hallet, teleomorph: Monographella nivalis (Schaffinit) E. Müller) destroyed overwintered rye sprouts (Valle 1958). Thus, the recommended sowing dates in southern Finland were as late as the first week of September (Valle 1958). Later, when insecticides and fungicides were more commonly used, earlier sowings during the two last weeks of August were recommended, based on findings that $265 \mathrm{DD}_{\text {base }}$ temperature $+5^{\circ} \mathrm{C}$ were needed for sufficiently strong tillering before winter (Mukula and Rantanen 1989).

Frit fly is the most destructive insect pest of winter rye in Finland. It typically has three generations per year although regional and year-toyear variation occurs. Frit fly overwinters in winter cereals and grasses. Stem-boring larvae of frit fly cause most severe damage by destroying spring cereal (spring generation) and winter cereal seed- lings (autumn generation). In addition, larvae from the summer generation can damage seeds in the spikes. The last heavy outbreaks of frit fly on winter rye occurred in the 1950s (Tiittanen 1959). Subsequently, decreased cultivation of winter cereals and grasses has decreased populations of frit fly in Finland (Kurppa 1990) and only local outbreaks have occurred. In Finland frit fly has been less important on spring cereals, whereas in Sweden for example it is a major problem on oats (Avena sativa L.) (Lindblad 1997).

Composition of weed floras in the field can be manipulated through crop rotation. Moreover, sowing time is important as there are differences in the weed flora under winter and spring sown cereals (Hallgren and Fogelfors 1995, Hald 1999). In Finland, changes in weed flora in spring cereals are well described (Hyvönen et al. 2003), but the latest weed survey in winter cereals in Finland is from the early 1970s (Raatikainen et al. 1978). The weeds with highest average weight $\left(\mathrm{kg} \mathrm{ha}^{-1}\right)$ were then scentless mayweed (Tripleurospermun inodorum Schultz Bip.) and couch grass (Elymus repens (L.) Gould). Currently it is common practice to control broad-leaved weeds with herbicides in early May, but not in the autumn. Using such a strategy it is assumed firstly that weeds that emerge in the autumn do not interfere seriously with the growth of rye during its early stages and secondly that some weeds do not overwinter. Thus, need for chemical weed control is difficult to estimate and, on the other hand, herbicide application is seldom feasible under wet autumn conditions.

The objective of this project was to study whether manipulation of sowing time and introduction of new cultivars could minimize the need for direct crop protection measures in winter rye production. The occurrence of frit fly and weeds was investigated by monitoring the levels of infestation and infection both in the autumn and early spring in order to assess damage to rye production. Furthermore, the study attempted to assess effects of sowing time on early crop development of four different rye varieties. The occurrence of leaf rust and the importance of snow mould as causal agents of winter damage were also investigated but the results has been reported separately (Serenius et al. 2005). 
Vol. 15 (2006): 43-60.

\section{Material and methods}

\section{Field experiment}

The field trials were conducted in southwestern Finland where rye production is concentrated. The field trials were located at experimental sites of MTT in Jokioinen $\left(60^{\circ} 49^{\prime} \mathrm{N}, 23^{\circ} 28^{\prime} \mathrm{E}\right)$, Mietoinen $\left(60^{\circ} 33^{\prime} \mathrm{N}, 21^{\circ} 51^{\prime} \mathrm{E}\right)$ and Pälkäne $\left(61^{\circ} 20^{\prime} \mathrm{N}\right.$, $\left.24^{\circ} 13^{\prime} \mathrm{E}\right)$. The experiments were sown in autumn 1999 and 2000 and were set up as split-plot designs with four replicates. The main plot factor was sowing time: early (week 32; 9-11 Aug), normally recommended (week 34; 23-25 Aug) and late (week 36; 6-7 Sept) (Table 1). The subplot was variety: Anna, a Finnish population variety, Amilo, a Polish short population variety, Bor 7068, a short, Finnish population breeding line and two German hybrid varieties, Esprit in 1999 and Picasso in 2000.

The gross plot size was $1.5 \mathrm{~m}$ x $10 \mathrm{~m}$ with a net plot width of $1.25 \mathrm{~m}$. Seeds were sown at a rate of $500 \mathrm{~m}^{-2}$ and a row space of $12.5 \mathrm{~cm}$ in ten rows (in
Pälkäne twelve rows) per plot. Seeds were coated with fungicide (fenpiclonil, Beret 050 FS) and seedlings were sprayed with fungicide (prochloratz $450 \mathrm{~g}$ a.i. ha ${ }^{-1}$, Sportak) in autumn (Table 2). In 1999 , insecticide was applied to the crop only in Mietoinen, but in 2000 all rye plants were sprayed with deltamethrin at the 2-leaf stage to reduce effects of potential frit fly damage. In 2000, however, a fifth replicate without insecticide application was added to the field trials for evaluating effects of insecticide treatment. Fertilizer was applied according to standard recommendations but adjusted to cropping history and soil type in each field (Table 2).

\section{Weather conditions}

The autumns of 1999 and 2000 were exceptionally warm. In autumn 1999, the thermal growing season ended on 16-18 October (Table 3 ) and the daily mean temperature fell below zero on 14 November (Fig. 1). The mean temperature fell permanently below $12^{\circ} \mathrm{C}$ and $8^{\circ} \mathrm{C}$ on 4 and 9 October,

Table 1. Sowing, sprouting and sampling times of the field experiments.

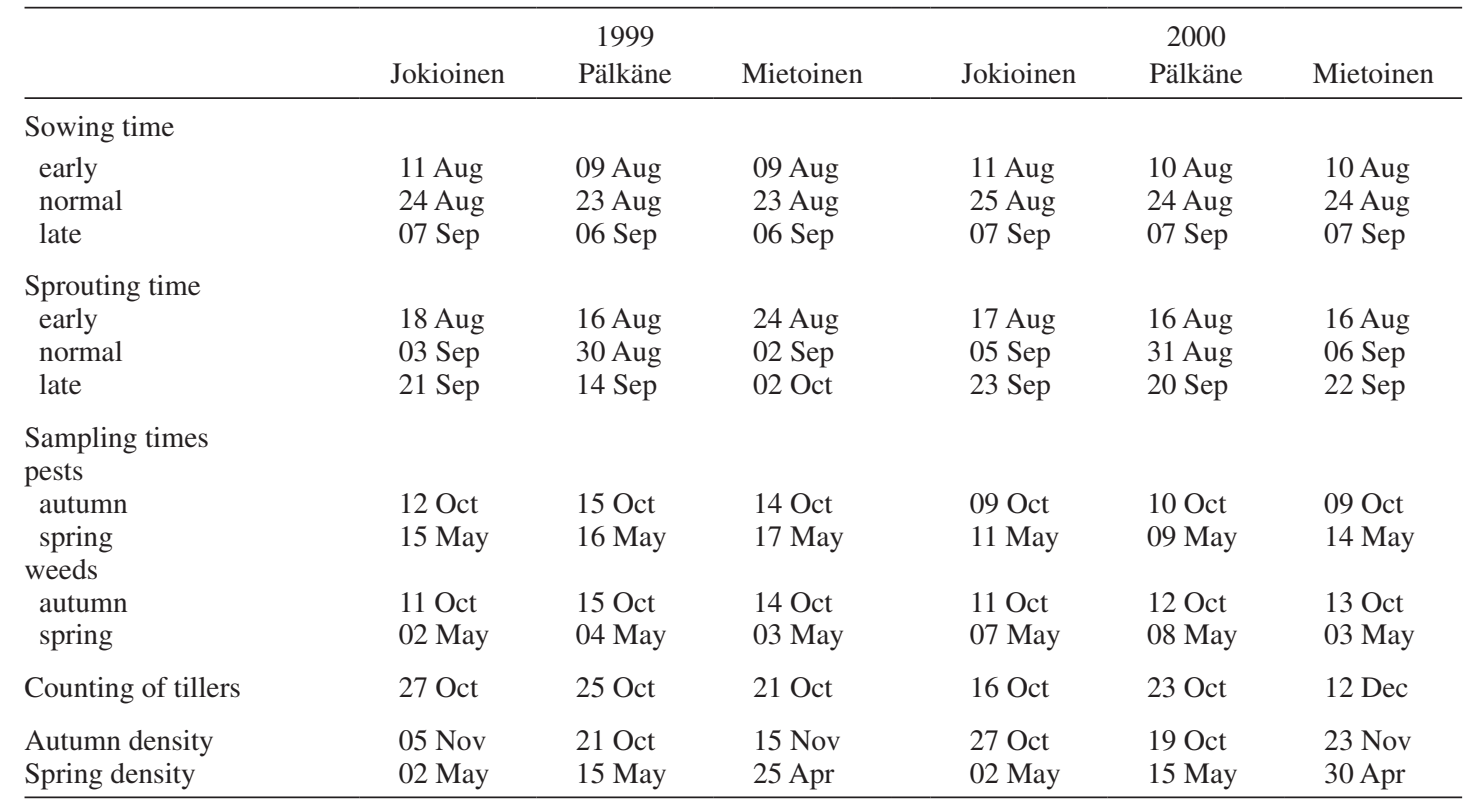


Huusela-Veistola, E. et al. Sowing time affects abundance of pests and weeds in rye

Table 2. Soil types, previous crops of the field trials and use of fertilizers insecticides and fungicides.

\begin{tabular}{|c|c|c|c|c|c|c|}
\hline & \multicolumn{3}{|c|}{1999} & \multicolumn{3}{|c|}{2000} \\
\hline & Jokioinen & Pälkäne & Mietoinen & Jokioinen & Pälkäne & Mietoinen \\
\hline soil type & sandy clay & very fine sand & sandy clay & sandy clay & very fine sand & sandy clay \\
\hline previous crop & grassland & fallow & fallow & grassland & timothy & red clover \\
\hline $\begin{array}{l}\text { fertilizers (N-P-K kg ha }-1) \\
\text { used in autumn }\end{array}$ & $33-18-38$ & $33-18-38$ & $35-19-41$ & $33-18-38$ & $33-18-38$ & $6-15-54$ \\
\hline insecticide treatment & no & no & dimethoate* & \multicolumn{3}{|c|}{ deltamethrin at 2-leaf stage } \\
\hline $\begin{array}{l}\text { fungicide treatment } \\
\text { (Sportak) }\end{array}$ & $14 \mathrm{Oct}$ & 19 Oct & $30 \mathrm{Nov}$ & 26 Oct & $03 \mathrm{Nov}$ & no \\
\hline
\end{tabular}

* dimethoate treatment 3 Sept 1999 in early and normal sowing times

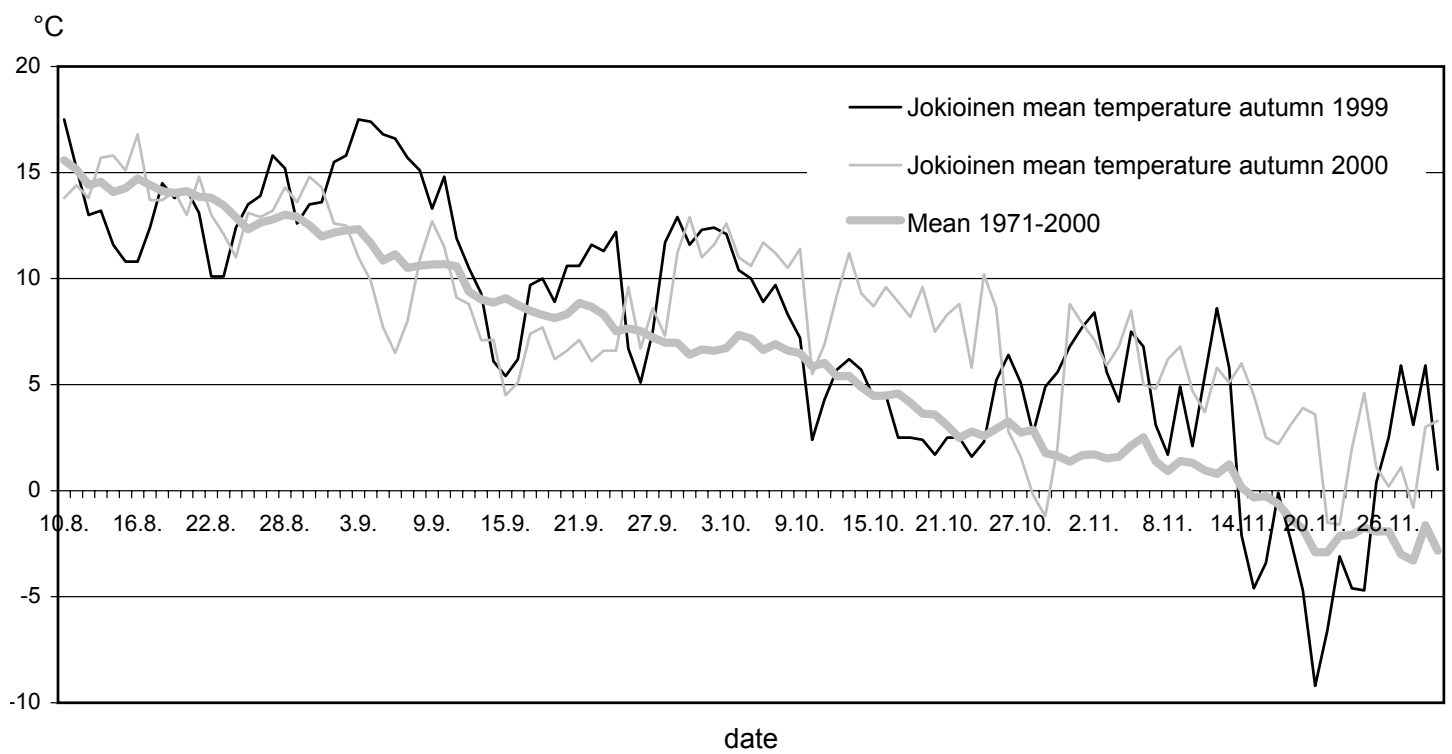

Fig. 1. Daily mean temperature $\left({ }^{\circ} \mathrm{C}\right)$ in Jokioinen in the autumn 1999 and 2000 compared with the values from 1971-2000 (Finnish Meteorological Institute).

respectively. In spring 2000 night frosts ceased on 3 April and the growing season started on 16-18 April (Table 3).

In autumn 2000 September was colder but October warmer than in autumn 1999 (Fig. 1). The mean daily temperature fell permanently below $12^{\circ} \mathrm{C}$ and $8^{\circ} \mathrm{C}$ on 4 and 8 October. The thermal growing season ended on 25 October (Table 3). The latest cold period in spring 2001 was 15 April and the growing season started on 22 April (Table $3)$.
The effective temperature sums from the latest sowing time to the end of the growing season were $171-242 \mathrm{DD}_{+5^{\circ} \mathrm{C}}$ in both autumns (Table 3). Precipitation in autumn and date of permanent snow cover by location are shown in Table 3 .

\section{Sampling}

The occurrence of pests and weeds was assessed in mid-October when the thermal growing season 
Vol. 15 (2006): 43-60.

Table 3. Effective temperature sum $\left({ }^{\circ \cdot} \mathrm{C} \mathrm{DD}\right.$, base $\left.+5^{\circ} \mathrm{C}\right)$ and precipitation $(\mathrm{mm})$ from sowing time to the end of the growing season in autumn 1999 and 2000. Date of permanent snow cover and the end and beginning of thermal growing season.

\begin{tabular}{|c|c|c|c|c|c|c|c|c|c|c|c|c|}
\hline & \multicolumn{6}{|c|}{1999} & \multicolumn{6}{|c|}{2000} \\
\hline & \multicolumn{2}{|c|}{ Jokioinen } & \multicolumn{2}{|c|}{ Pälkäne } & \multicolumn{2}{|c|}{ Mietoinen } & \multicolumn{2}{|c|}{ Jokioinen } & \multicolumn{2}{|c|}{ Pälkäne } & \multicolumn{2}{|c|}{ Mietoinen } \\
\hline & ${ }^{\circ} \mathrm{C}$ & $\mathrm{mm}$ & ${ }^{\circ} \mathrm{C}$ & $\mathrm{mm}$ & ${ }^{\circ} \mathrm{C}$ & $\mathrm{mm}$ & ${ }^{\circ} \mathrm{C}$ & $\mathrm{mm}$ & ${ }^{\circ} \mathrm{C}$ & $\mathrm{mm}$ & ${ }^{\circ} \mathrm{C}$ & $\mathrm{mm}$ \\
\hline \multicolumn{13}{|l|}{ Sowing time } \\
\hline early & 409 & 166 & 463 & 181 & 510 & 210 & 402 & 136 & 437 & 122 & 482 & 166 \\
\hline normal & 314 & 160 & 344 & 163 & 383 & 204 & 276 & 77 & 307 & 67 & 246 & 130 \\
\hline late & 171 & 143 & 200 & 136 & 232 & 180 & 190 & 73 & 202 & 64 & 242 & 109 \\
\hline Permanent snow & \multicolumn{2}{|c|}{$\begin{array}{l}2 \text { Dec } 1999- \\
8 \text { Apr } 2000\end{array}$} & \multicolumn{2}{|c|}{$\begin{array}{l}\text { 4 Dec } 1999- \\
13 \text { Apr } 2000\end{array}$} & \multicolumn{2}{|c|}{$\begin{array}{l}14 \text { Dec } 1999- \\
6 \text { Apr } 2000\end{array}$} & \multicolumn{2}{|c|}{$\begin{array}{l}19 \text { Dec } 2000- \\
1 \text { Apr } 2001\end{array}$} & \multicolumn{2}{|c|}{$\begin{array}{l}22 \text { Dec } 2000- \\
7 \text { Apr } 2000\end{array}$} & \multicolumn{2}{|c|}{$\begin{array}{l}24 \operatorname{Dec} 2000 \\
18 \text { Mar } 2000\end{array}$} \\
\hline \multicolumn{13}{|l|}{ Thermal growing season } \\
\hline - end & \multirow{2}{*}{\multicolumn{2}{|c|}{14 Oct 1999}} & \multirow{2}{*}{\multicolumn{2}{|c|}{14 Oct 1999}} & \multicolumn{2}{|c|}{14 Oct 1999} & \multicolumn{2}{|c|}{25 Oct 2000} & \multicolumn{2}{|c|}{25 Oct 2000} & \multicolumn{2}{|c|}{25 Oct 2000} \\
\hline - restart & & & & & \multicolumn{2}{|c|}{16 Apr 2000} & \multicolumn{2}{|c|}{22 Apr 2001} & \multicolumn{2}{|c|}{22 Apr 2001} & \multicolumn{2}{|c|}{22 Apr 2001} \\
\hline
\end{tabular}

had ceased and again in early May in the beginning of the growing season (Table 1). Pests were assessed on 20 randomly collected plants per plot. The length and dry biomass of seedlings were measured. In addition, number of tillers per plant and tillers damaged by frit fly were counted. The number of larvae and pupae of the frit fly and the Hessian fly (Mayetiola destructor Say) were counted per plant. Percentages of infected plants and damaged tillers were used in the statistical analyses of pest occurrence. Results from insecticide treated trials were omitted from analyses of sowing time effects.

The weed density in autumn was assessed by counting the numbers of weed species in a circular frame of $0.25 \mathrm{~m}^{2}$ from two sites per plot. The same sample areas were re-assessed in early spring and both the weed density and the biomass of weeds were determined (Table 1). The weed biomass was determined after the samples had been dried in an air-flow drier at $40^{\circ} \mathrm{C}$. The nomenclature of weed species follows that of Hämet-Ahti et al. (1998).

To study the early growth of rye, the number of tillers was counted in one meter of each of two rows per plot in October, except at Mietoinen in December 2000 (Table 1). The crop density (\%) was assessed visually in autumn and in spring (Table 1).

\section{Statistical methods}

Statistical analyses were performed using PROC MIXED in SAS/STAT Software (Littell et al. 1996). All experimental designs, randomisations and statistical analyses, except those for repeated measurements, were performed according to Gomez and Gomez (1984). Statistical analyses with repeated measurements were performed according to Gumpertz and Brownie (1993). Assumptions of models were checked using graphical methods; box-plots for normality of errors and plots of residuals for constancy of error variances (Neter et al. 1996) using PROC UNIVARIATE of SAS.

Percentage data of pest infestation were arcsine (square root) transformed prior to analysis as necessary to satisfy conditions of normality and homogeneity of variances. Weed density and numbers of single weeds were analysed using square root transformed data. Total weed biomass was analysed using logarithmic transformed data, but single species with untransformed data (Cousens 1988). The differences in pest and weed levels in crops among sowing times and varieties in autumn and spring samples were assessed using analysis of variance for repeated measures with sampling time as a repeated factor in a split-plot design. Bio- 
mass and length of seedlings, crop density and number of tillers in the autumn were analysed without the repeated factor.

Data from all three locations (experiment sites) were analysed together, but data for different years were analysed separately because of different treatments (varieties, insecticide use) between years. If the main effects were statistically significant in ANOVA, Tukey's HSD test was used to determine significances of mean differences among factors. If the interaction effects were significant, comparisons were done within each level of the main-plot or sub-plot factor. All presented estimates were transformed to the original scale. The standard error of the estimated mean, however, could not be transformed to the original scale.

\section{Results}

\section{Early crop development}

The establishment of rye in early-sown plots was more uneven in 1999 than in 2000, especially in Jokioinen and Pälkäne, where only $81 \%$ of the plot area was covered by seedlings. In autumn 2000, the establishment was complete in Mietoinen (100\%), but lower in Pälkäne (98\%) and Jokioinen (88\%). The establishment was highest in late sown plots during both years. In 1999, no significant differences in establishment were recorded among varieties. In 2000, varieties differed significantly ( $\mathrm{F}=17.69, \mathrm{P}<0.001$, data not shown $)$ and Picasso formed the densest stands, on average 97 vs. 94$96 \%$.

The number of tillers $\mathrm{m}^{-2}$, counted in October, except in Mietoinen where it was done in December 2000, was affected by location, sowing time and variety (interaction $\mathrm{P}<0.001$ ) in both years (Fig. 2). In 1999, the low number of tillers in early sown rye in Pälkäne was due to high pest levels. The early sown rye could produce more than 900 tillers per square meter in the absence of high pest load on plots. In 1999, Esprit produced more tillers per plant $(\mathrm{P}<0.05)$ than Anna and Bor 7068 in early (7.9 vs. 6.6 and 6.3 ) and normal sowings (5.6 vs. 4.8), and had the highest number of tillers $\mathrm{m}^{-2}$ $\left(802 \mathrm{~m}^{-2}, \mathrm{P}<0.001\right)$. In 2000 , the number of tillers $\mathrm{m}^{-2}$ was significantly highest in Picasso $(\mathrm{P}<0.001)$. The difference was most obvious in late sowing (754 vs. 564-571 tillers $\mathrm{m}^{-2}$ ).

Seedling size (length and weight) was determined in October. In both years, the largest seedlings were collected in Pälkäne and the smallest in Jokioinen (Fig. 3). The size of seedlings was highly dependent also on the sowing time $(\mathrm{P}<0.001)$ : the earlier the sowing, the taller seedlings. The early sown seedlings reached $20 \mathrm{~cm}$ in 1999 and $25 \mathrm{~cm}$ in 2000. However, in 1999 the difference in seedling length between early and normal sowing time was not significant. In 1999, no significant differences in dry weight of the varieties were detected. In 2000, weights of seedlings of different varieties were significantly different $(\mathrm{F}=5.03, \mathrm{P}=$ 0.003). Seedlings of Anna were significantly longer (21.4 vs. $18.8-20.2 \mathrm{~cm})$ and heavier (5.0 vs. $4.1-4.3 \mathrm{~g}$ ) than those of other varieties in 2000 .

\section{Pests}

Early sown rye was severely attacked by frit flies in autumn 1999 (Fig. 4, Table 4). Percentage of plants infested by frit flies was highest in Pälkäne and Jokioinen, where 78 and $72 \%$ of early sown plants were infested and frit fly damage decreased tiller number (see previous). In Mietoinen infestation level was clearly lower as a result of insecticide treatment. In spring 2000, the infestation levels were markedly lower than in the previous autumn. However, the effect of sowing time was similar in Jokioinen and Pälkäne (Fig. 4). The percentage of infested plants did not differ among rye varieties (Table 4). Percentage of infested tillers depended on sowing time location and sampling time, but not on variety, similarly as for percentage of infested plants (Fig. 4, Table 4).

In autumn 2000 all trials (except one extra replicate) were sprayed with insecticide at the 2-leaf stage and the percentage of plants infested by frit flies was clearly lower than in the previous year. However, infestation level was higher in early than late sown rye stands. Effect of insecticide treat- 
Vol. 15 (2006): 43-60.

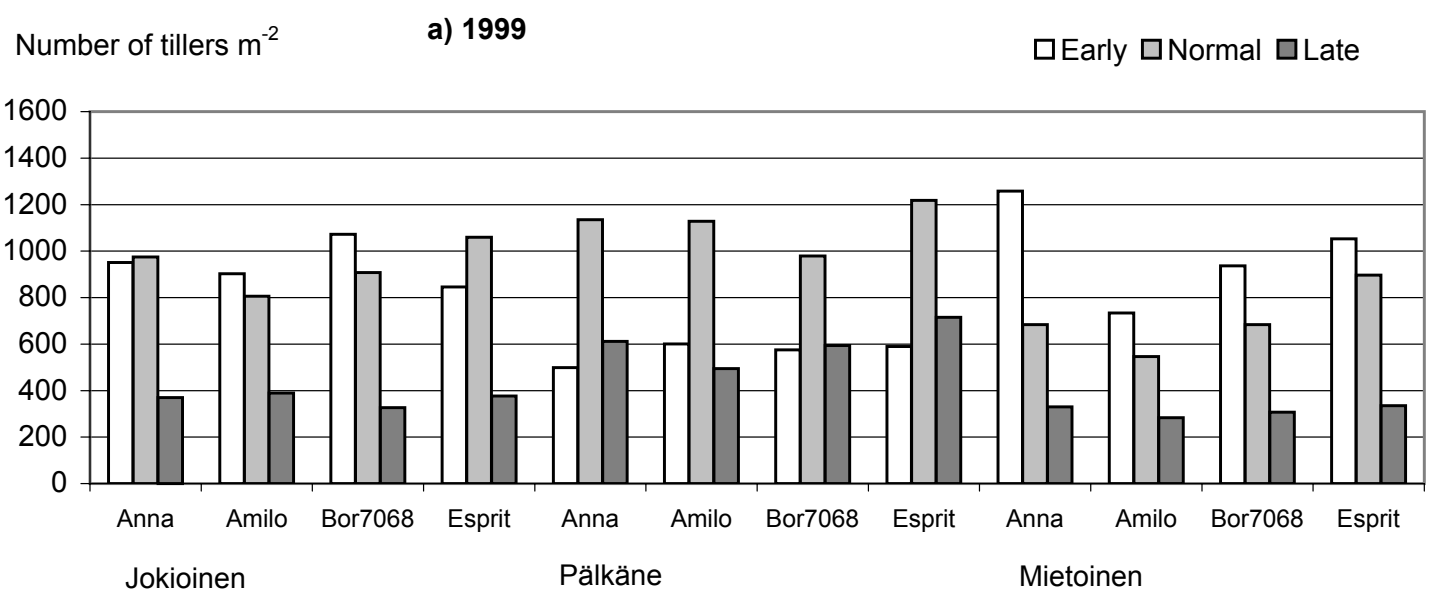

Number of tillers $\mathrm{m}^{-2}$

b) 2000

$\square$ Early $\square$ Normal $\square$ Late

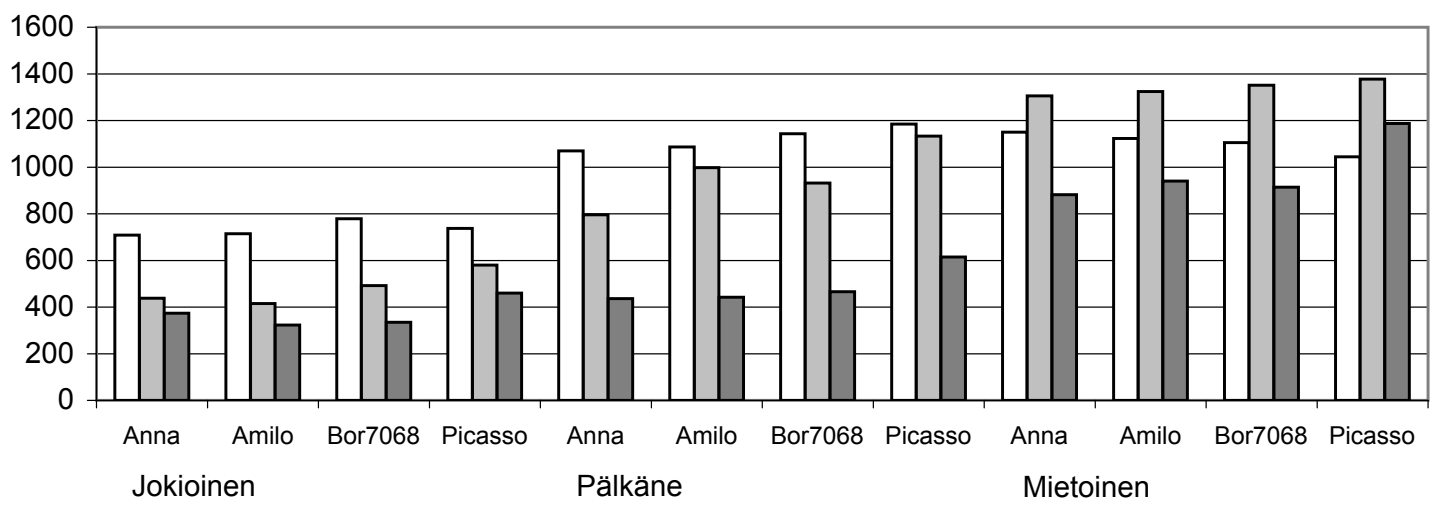

Fig. 2. Tillering of rye seedlings by location, variety and sowing time in October a) 1999 and b) 2000. Sowing times: early $=$ week 32 , normal $=$ week 34 , late $=$ week 36 .

ment was demonstrated in early sown rye in Jokioinen and Mietoinen and in normal time sown rye in Pälkäne (Table 5). In spring 2001, infestation levels of early sown plants were less than half of those in the autumn. Frit fly numbers differed among rye varieties significantly $(\mathrm{F}=3.27, \mathrm{P}<0.05)$, but this had no agricultural relevance. Infestation level was highest in Amilo (2.6\%) and lowest in Picasso (1.1\%).

In both years of the experiment the early sown rye was infested with Hessian flies. In the first year the infestation level was approximately $7 \%$ in the autumn and $3 \%$ in the spring. Despite insecticide application in the second year the infestation level was higher approximately $15 \%$ in the autumn and $9 \%$ in the spring, but it depended also on variety and location (interaction $\mathrm{F}=2.72, \mathrm{P}=0.022$ ). In autumn 2000 insecticide treatment did not decrease infestation level of Hessian fly (Table 6). Overall, the highest infestations in the autumn were found in Jokioinen in insecticide treated Amilo (35\%) and Picasso (31\%). 
Huusela-Veistola, E. et al. Sowing time affects abundance of pests and weeds in rye

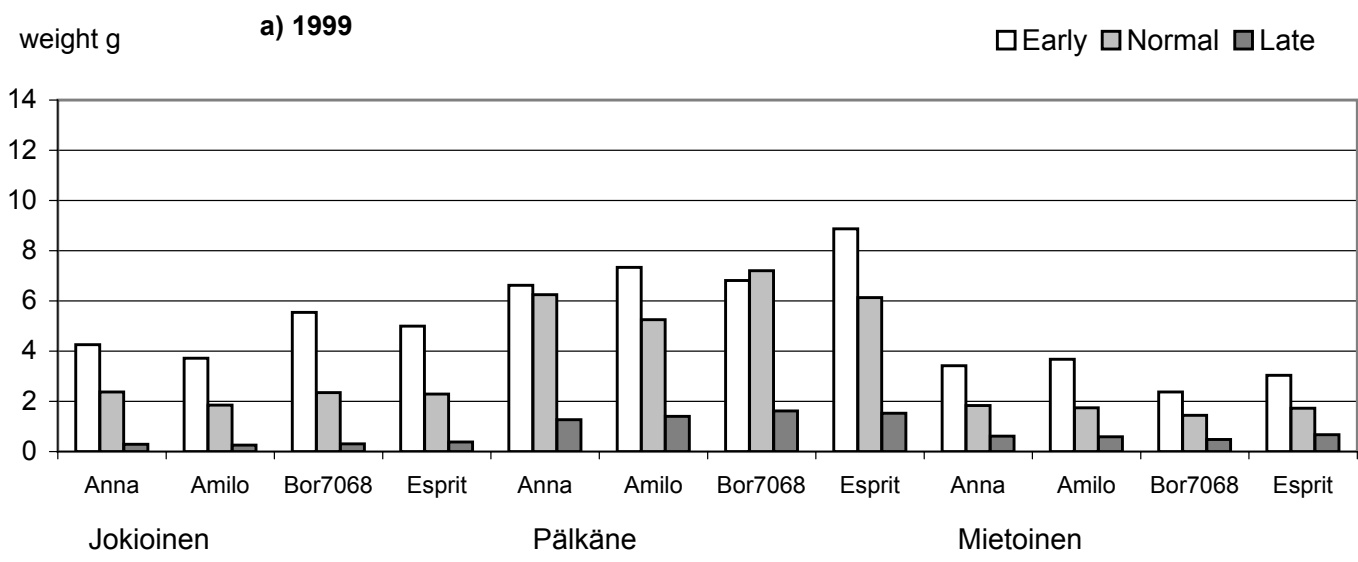

$\begin{array}{ll}\text { weight } g & \text { b) } 2000\end{array}$

口Early $\square$ Normal $\square$ Late

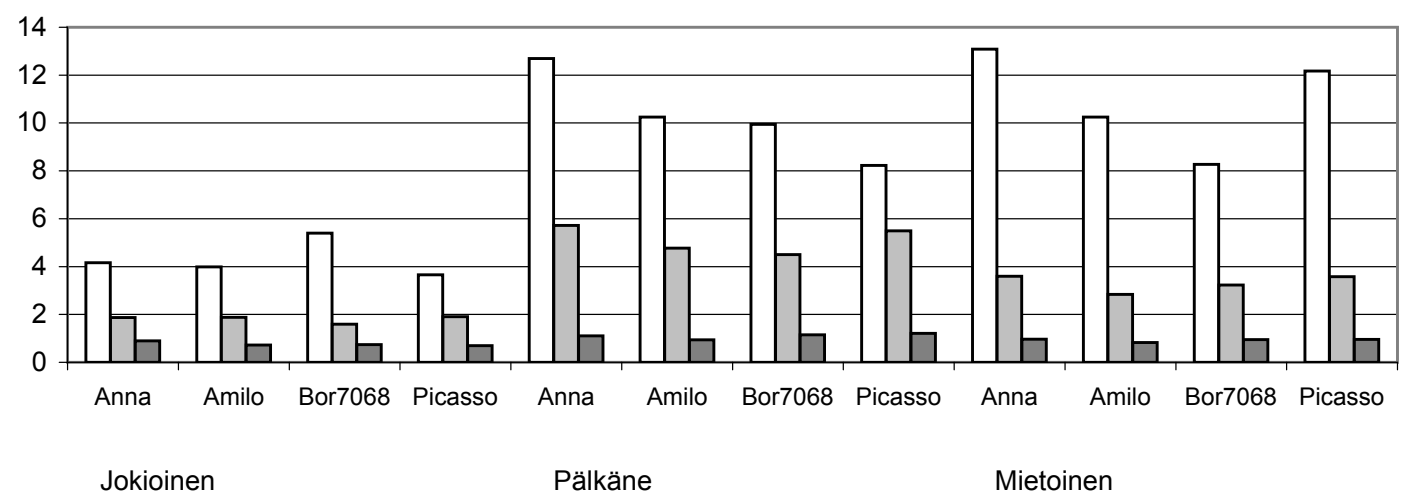

Fig. 3. Dry weight (g) of 20 rye seedlings by location, variety and sowing time in October a) 1999 and b) 2000. Sowing times: early $=$ week 32 , normal $=$ week 34 , late $=$ week 36 .
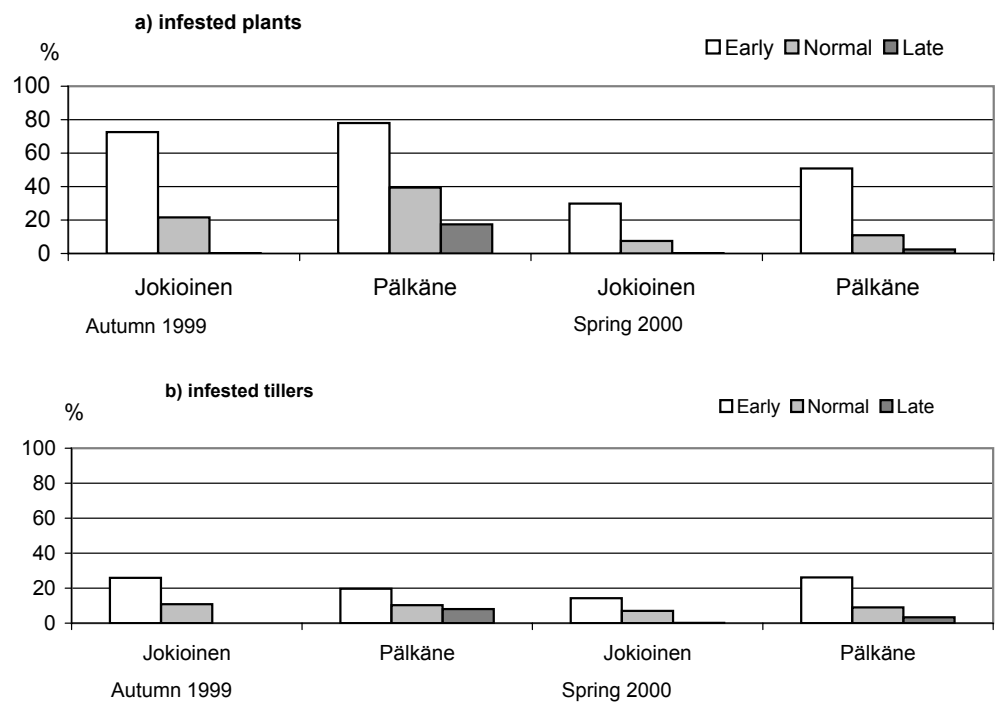

Fig. 4. Percentage of plants (a) and tillers (b) infested by frit fly (Oscinella frit) by sowing time in Jokioinen and Pälkäne in the autumn 1999 and spring 2000. Sowing times: early $=$ week 32 , normal $=$ week 34 , late $=$ week 36 . 
Vol. 15 (2006): 43-60.

Table 4. ANOVA for percentage of plants and tillers infested by frit fly (Oscinella frit). Sampling in October 1999 and May 2000. Data from Mietoinen not included in analyses.

\begin{tabular}{|c|c|c|c|c|}
\hline & \multicolumn{2}{|c|}{$\%$ infested plants } & \multicolumn{2}{|c|}{$\%$ infested tillers } \\
\hline & d.f. & $\mathrm{F}$ & d.f. & $\mathrm{F}$ \\
\hline location & 1,5 & $18.19 * *$ & 1,5 & $16.88 * *$ \\
\hline sowing time & 2,10 & $141 \quad * * *$ & 2,10 & $87.97 * * *$ \\
\hline sowing time $\mathrm{x}$ location & 2,10 & 1.61 & 2,10 & $8.87 * *$ \\
\hline variety & 3,45 & 1.21 & 3,45 & $2.33^{\circ}$ \\
\hline variety $\mathrm{x}$ location & 3,45 & 0.58 & 3,45 & $2.67^{\circ}$ \\
\hline sowing time $\mathrm{x}$ variety & 6,45 & 0.18 & 6,45 & 0.4 \\
\hline sowing time $\mathrm{x}$ variety $\mathrm{x}$ location & 6,45 & 0.7 & 6,45 & 0.2 \\
\hline sampling time & 1,5 & $63.19 * * *$ & 1,5 & $6.74 *$ \\
\hline location $\mathrm{x}$ sampling time & 1,5 & 1.73 & 1,5 & 1.89 \\
\hline sowing time $\mathrm{x}$ sampling time & 2,10 & $8.21 * * *$ & 2,10 & 0.04 \\
\hline sowing time $\mathrm{x}$ location $\mathrm{x}$ sampling time & 2,10 & $7.42 *$ & 2,10 & $12.18 * *$ \\
\hline \multirow{4}{*}{$\begin{array}{l}\text { variety } \mathrm{x} \text { sampling time } \\
\text { variety } \mathrm{x} \text { location } \mathrm{x} \text { sampling time } \\
\text { sowing time } \mathrm{x} \text { variety } \mathrm{x} \text { sampling time } \\
\text { sowing time } \mathrm{x} \text { variety } \mathrm{x} \text { location } \mathrm{x} \text { sampling time }\end{array}$} & 3,45 & 0.5 & 3,45 & 2.07 \\
\hline & 3,45 & 0.66 & 3,45 & 1.84 \\
\hline & 6,45 & 1.42 & 6,45 & 0.24 \\
\hline & 6,45 & 0.18 & 6,45 & 0.15 \\
\hline$\circ, \mathrm{P}<0.1 ; *, \mathrm{P}<0.05 ; * *, \mathrm{P}<0.01 ; * * *$ & & & & \\
\hline
\end{tabular}

Table 5. Percentage of plants infested by frit fly in autumn 2000 in insecticide treated plots $(n=16)$ and in untreated plots $(n=4)$.

Percentage of plants infected by frit fly $(\%)$

Jokioinen Pälkäne Mietoinen

\begin{tabular}{llll}
\hline $\begin{array}{l}\text { Early sowing time } \\
\text { insecticide treatment }\end{array}$ & 11 & 16 & 11 \\
no insecticide treatment & 26 & 19 & 24 \\
Normal sowing time & & & \\
$\quad$ insecticide treatment & 2 & 14 & 2 \\
no insecticide treatment & 1 & 40 & 9 \\
Late sowing time & & & \\
insecticide treatment & 0 & 2 & 0 \\
no insecticide treatment & 0 & 1 & 1 \\
\hline
\end{tabular}

\section{Weeds}

Both in the autumn 1999 and 2000 the highest weed densities were found in early sown plots (Fig. 5). In the first year weed densities did not differ significantly among localities or varieties, whereas one year later the difference in weed densities at different sowing times depended on location, variety and sampling time (Table 7). The highest weed densities were observed then in Pälkäne and the lowest in Mietoinen and the weed densities in autumn 2000 (on average 148 weeds $\mathrm{m}^{-2}$ ) were considerably higher than in the spring 2001 (73 weeds $\mathrm{m}^{-2}$ ). Moreover, weed densities in Picasso plots were slightly lower (139 vs. 149-151 weeds $\mathrm{m}^{-2}$ ) than in the plots of other varieties.

Weeds over-wintered poorly in 2000/2001, though there were differences among the locations (Fig. 5). A large quantity of weeds died at all locations except Jokioinen. The sowing time affected over-wintering so that in the early sown plots weed mortality was higher than in the later sown plots. This can be explained with the differences in botanical composition between sowing times (Table 9).

Delayed sowing reduced weed emergence effectively and as a consequence the weed biomass in the spring 2000 was relatively low, although it differed somewhat among locations (Table 8, Fig. 6). In spring 2001, the difference in weed biomass among locations was clear; in Mietoinen the weed biomass was negligible at all sowing times. In Jokioinen, the weed biomass was highest in early sown plots and lowest in late sown plots, whereas in Pälkäne the result was contrary due to the sur- 
Huusela-Veistola, E. et al. Sowing time affects abundance of pests and weeds in rye

Table 6. Percentage of early sown rye plants infested by Hessian fly (Mayetiola destructor) by variety in autumn 1999 and 2000. Insecticide application in 1999 only in Mietoinen but in 2000 in all locations. In 2000 four insecticide treated replicates and one untreated replicate.

\begin{tabular}{|c|c|c|c|c|c|c|c|}
\hline \multirow[t]{2}{*}{ Location } & \multirow[t]{2}{*}{ insecticide treatment } & \multicolumn{5}{|c|}{ variety } & \multirow[b]{2}{*}{ mean } \\
\hline & & Anna & Amilo & Bor 1068 & Esprit & Picasso & \\
\hline \multicolumn{8}{|l|}{1999} \\
\hline Jokioinen & no $(n=4)$ & 5.8 & 5.2 & 11.4 & 13.5 & & 9.0 \\
\hline Pälkäne & no $(n=4)$ & 4.9 & 7.6 & 4.6 & 17.3 & & 8.6 \\
\hline Mietoinen & yes $(n=4)$ & 4.5 & 4.0 & 6.1 & 2.9 & & 4.4 \\
\hline \multicolumn{8}{|l|}{2000} \\
\hline \multirow[t]{2}{*}{ Jokioinen } & yes $(n=4)$ & 12.5 & 35.0 & 16.2 & & 31.2 & 23.75 \\
\hline & no $(\mathrm{n}=1)$ & 15.0 & 20.0 & 20.0 & & 10.0 & 16.3 \\
\hline \multirow[t]{2}{*}{ Pälkäne } & yes $(n=4)$ & 2.4 & 15.0 & 7.5 & & 10.0 & 8.73 \\
\hline & no $(\mathrm{n}=1)$ & 0.0 & 10.0 & 5.0 & & 10.0 & 6.3 \\
\hline Mietoinen & yes $(n=4)$ & 12.5 & 20.0 & 10.0 & & 7.5 & 12.5 \\
\hline
\end{tabular}
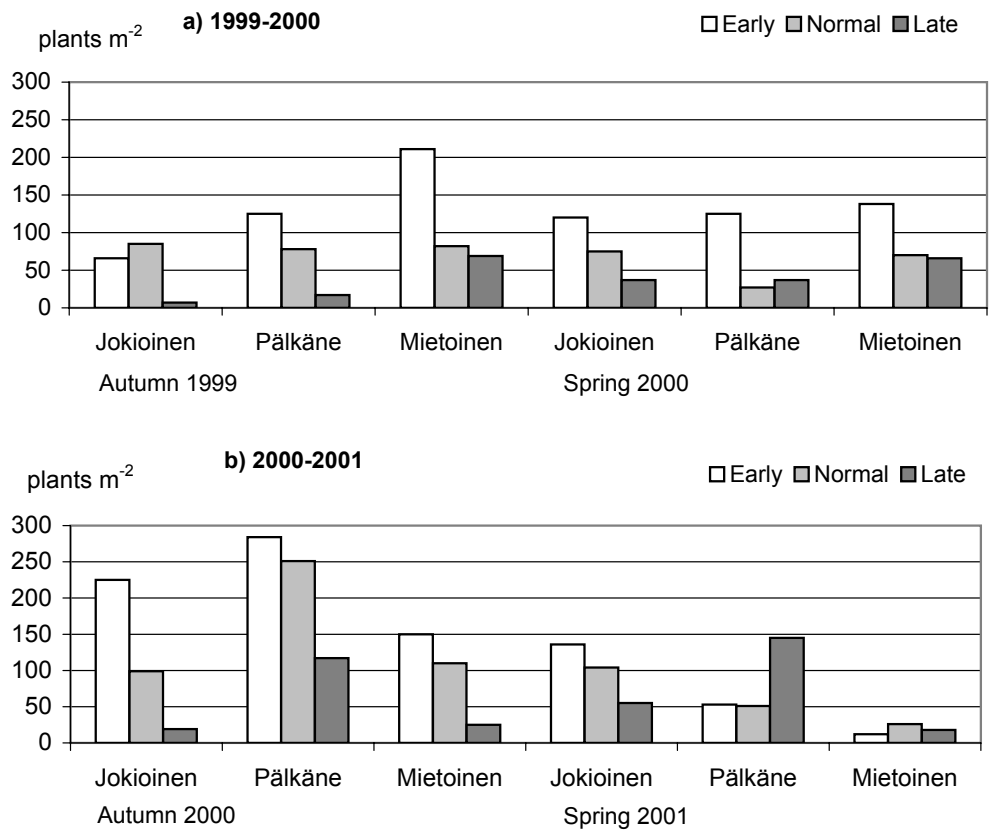

Fig. 5. Weed density by location and sowing time in autumn and spring a) 1999-2000 and b) 2000-2001. Sowing times: early $=$ week 32, normal $=$ week 34 , late $=$ week 36 .

vival of Viola arvensis Murray. On average, weed biomass accounted for $13 \%$ of the total biomass of the crop stand. The residuals from ANOVA did not indicate any correlation between the total weed biomass and biomass of rye in early spring.
The average number of weed species per field was 16 (min. 12, max. 22) in the autumn and 15 in spring (min. 11, max. 22). However, after the harsh winter of 2000/2001 there was a substantial decline in the number of weed species in Mietoinen 
Vol. 15 (2006): 43-60.

Table 7. ANOVA for weed density (plants $\mathrm{m}^{-2}$ ). Sampling in October and May.

\begin{tabular}{lcccc}
\hline & \multicolumn{2}{c}{$1999-2000$} & \multicolumn{2}{c}{$2000-2001$} \\
& d.f. & $\mathrm{F}$ & d.f. & $\mathrm{F}$ \\
\hline location & 2,9 & 1.54 & 2,9 & $14.45 * *$ \\
sowing time & 2,16 & $15.37 * * *$ & 2,18 & $8.76 * *$ \\
sowing time x location & 4,16 & 1.18 & 4,18 & $2.58 *$ \\
variety & 3,72 & 0.63 & 3,81 & $5.75 * *$ \\
variety x location & 6,72 & 0.80 & 6,81 & $3.39 * *$ \\
sowing time x variety & 6,72 & 0.35 & 6,81 & $2.322^{\circ}$ \\
sowing time x variety x location & 12,72 & 1.08 & 12,81 & 0.25 \\
sampling time & 1,9 & 0.02 & 1,9 & $113.65 * * *$ \\
location x sampling time & 2,9 & 2.19 & 2,9 & $28.80 * * *$ \\
sowing time x sampling time & 2,16 & $3.90 *$ & 2,18 & $56.28 * * *$ \\
sowing time x location x sampling time & 4,16 & 1.52 & 4,18 & $3.49 *$ \\
variety x sampling time & 3,72 & 0.15 & 3,81 & 1.57 \\
variety x location x sampling time & 6,72 & 0.36 & 6,81 & $3.10 * *$ \\
sowing time x variety x sampling time & 6,72 & 0.74 & 6,81 & $3.47 * *$ \\
sowing time x variety x location $\mathrm{x}$ sampling time & 12,72 & 0.96 & 12,81 & 0.68 \\
\multicolumn{1}{c}{$\quad \mathrm{P}<0.1 ; *, \mathrm{P}<0.05 ; * *, \mathrm{P}<0.01 ; * * *, \mathrm{P}<0.001$} & & & & \\
\hline
\end{tabular}

Fig. 6. Weed biomass by location and sowing time in spring 2000 and 2001. Sowing times: early $=$ week 32 , normal $=$ week 34 , late $=$ week 36 .

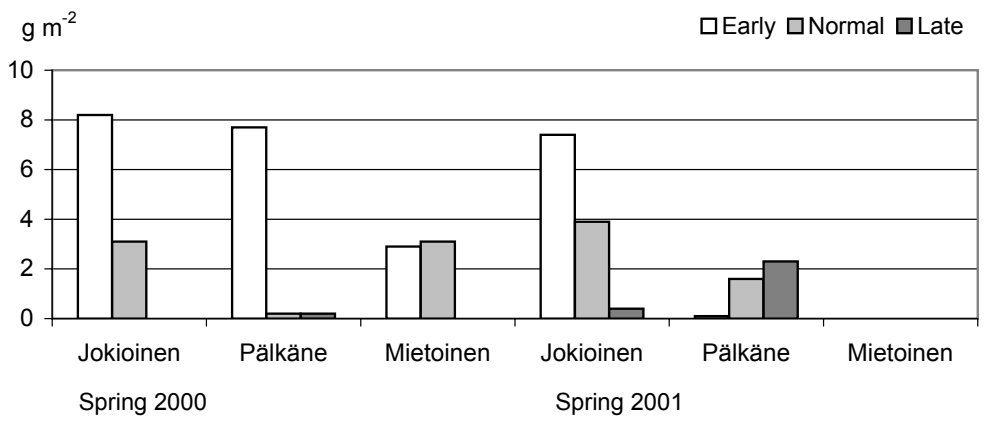

Table 8. ANOVA for weed biomass $\left(\mathrm{g} \mathrm{m}^{-2}\right)$ harvested in May 2000 and 2001.

\begin{tabular}{|c|c|c|c|c|}
\hline & \multicolumn{2}{|c|}{ Spring 2000} & \multicolumn{2}{|c|}{ Spring 2001} \\
\hline & d.f. & $\mathrm{F}$ & d.f. & $\mathrm{F}$ \\
\hline location & 2,9 & 1.74 & 2,9 & $53.52 * * *$ \\
\hline sowing time & 2,16 & $51.36 * * *$ & 2,18 & $3.77^{\circ}$ \\
\hline sowing time $\mathrm{x}$ location & 4,16 & $12.97 * * *$ & 4,18 & $5.19 * *$ \\
\hline variety & 3,72 & 0.73 & 3,81 & 0.92 \\
\hline variety $\mathrm{x}$ location & 6,72 & 0.96 & 6,81 & 1.48 \\
\hline sowing time $\mathrm{x}$ variety & 6,72 & 1.28 & 6,81 & 1.48 \\
\hline sowing time $\mathrm{x}$ variety $\mathrm{x}$ location & 12,72 & 0.46 & 12,81 & 0.75 \\
\hline${ }^{\circ}, \mathrm{P}<0.1 ; *, \mathrm{P}<0.05 ; * *$ & & & & \\
\hline
\end{tabular}

and Pälkäne: 7-8 species, primarily summer annuals including Galeopsis spp., Fallopia convolvulus and volunteer oilseed turnip rape, vanished during the winter.
The density and biomass of weed species are shown in Tables 9 and 10. T. inodorum emerged in the first autumn (1999) in early and normal sowings at every location and survived over the winter 
1999/2000. The second autumn (2000) differed from the previous as T. inodorum did not emerge in Jokioinen and at other locations almost every $T$. inodorum seedling died during the winter 2000/2001. T. inodorum was most abundant in Pälkäne and in spring 2000 it produced 10 times more biomass than elsewhere in early sown plots.

Stellaria media (L.) Vill. was most abundant in early sown plots, but it did not over-winter very well. Viola arvensis produced more seedlings and the highest biomass in early sown plots, except in Pälkäne 2000/2001.

Myosotis arvensis (L.) Hill predominated in Pälkäne and especially in spring 2000. Lamium purpureum L. emerged only in Mietoinen and Jokioinen but produced only small amounts of biomass in spring 2000. In the second autumn L. purpureum emerged mainly in early sown plots, but it did not over-winter.

Galium spurium L. emerged in Jokioinen in the second year and was most abundant in the plots sown at the normal time. Typical weeds in early sown plots were Capsella bursa-pastoris (L.) Medicus in Jokioinen in 1999/2000 and Thlaspi arvense L. in Jokioinen in autumn 2000 and in Mietoinen both in autumns. T. arvense did not survive over the winter 2000/2001.

\section{Discussion}

\section{Insect pests}

The risk of frit fly problems was clearly highest in early sown winter rye although in small trial plots damage can be overestimated. In Pälkäne, where emergence of seedlings was faster than at other locations, frit flies also caused damage to rye sown at the normal time. According to previous sowing time trials (Tiittanen 1959, Kanervo and Vappula 1965) 24 August has been considered as a limit after which frit fly damage only rarely occurs in Finland. However, frit fly damage levels vary widely. In particular years, when early sown winter rye has been heavily damaged by frit fly, yields were only
$49-70 \%$ of those from rye sown at the normal time (Linnomäki 1958). When the frit fly has not been abundant the best rye yields have been recorded from early sown crops (Tiittanen 1959) or the yields have been similar to yields recorded from rye sown at the normal time (28 August) (Linnomäki 1958).

The risk of frit fly damage is high during warm autumns because damage is temperature dependent, and weather affects flight, egg-laying activity and larval development rate. Infestation rates increase with increasing temperature. The threshold of $14^{\circ} \mathrm{C}$ maximum temperature for flight activity of frit fly in spring has been recorded in oats in Sweden (Lindblad 1997). The developmental threshold for frit fly larvae is $7-8^{\circ} \mathrm{C}$ (Riggert 1935 , Nielsen and Nielsen 1984) and $12^{\circ} \mathrm{C}$ (Tiittanen 1959). According to Tiittanen (1959) if the autumn temperature is low (below $12^{\circ} \mathrm{C}$ ) frit fly larvae develop slowly and damage is small despite moderate infestation levels. In our experiments, the daily mean temperature did not decrease permanently below $12^{\circ} \mathrm{C}$ until 4 Oct 1999 and 10 Oct 2000 but in autumn 2000 colder periods occurred in September.

The highest damage level occurs when large numbers of ovipositing adult frit flies coincide with the most susceptible seedling development stage (Van Emden and Way 1973). This is when the stem is sufficiently young to allow entry of larvae and old enough to allow larvae to develop to pupation. Furthermore, most severe damage occurs when large numbers of frit fly larvae coincide with relatively slow seedling growth rates (Clements et al. 1990). If seedlings are vigorous they can compensate for frit fly damage by tillering, but if damage is severe, as in early sowings in Pälkäne and Jokioinen 1999, frit flies decrease the tiller number. According to our results, infestation of winter rye decrease substantially by adjusting (late) sowing time. Failing that, frit fly damage at early sowings can be managed by spraying rye seedlings with insecticides at a susceptible 2-leaf stage. Costs of insecticides vary from 8 to $17 €$ $\mathrm{ha}^{-1}$, depending on active ingredient or product. On an average, a yield increase of $180 \mathrm{~kg} \mathrm{ha}^{-1}$ will cover costs of labour and insecticides. While the 
Vol. 15 (2006): 43-60.
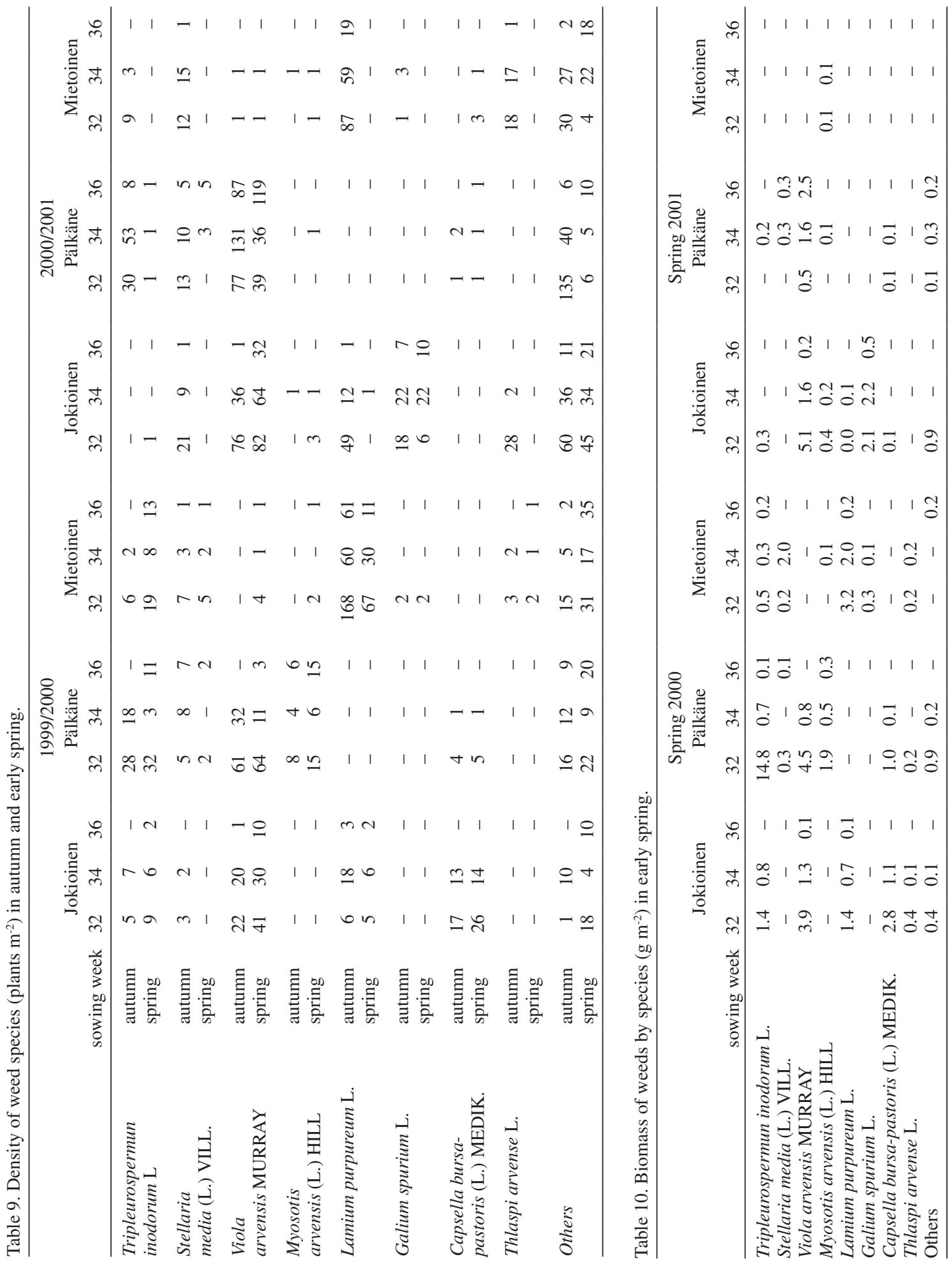
need for plant protection can be evaluated by monitoring flying frit fly with yellow sticky traps during seedling emergence the precise economical threshold for control is difficult to establish (Huusela-Veistola and Ketola 2004).

Although certain cereal varieties can demonstrate resistance to frit fly (Jonasson 1991, Ryabchenko and Merkushina 1994, Sinelnikov 1996), our results indicated that the difference in frit fly infestation level among rye varieties was small. A statistically significant difference among varieties was found only in autumn 2000 when frit fly levels were very low as a result of insecticide treatment. This had no practical significance however. In the previous autumn, when frit fly levels were high and no insecticides were used, no difference among varieties was found.

Early sown rye was infested also by Hessian flies in both years. Hessian fly has been a particular problem in relay intercropping of cereals in winter wheat (Triticum aestivum L.), but also in winter rye, which is sown in spring (Huusela-Veistola et al. 2001). Control of Hessian fly with insecticides has been very difficult in relay intercropping (Huusela-Veistola and Känkänen 2000). In the present study, insecticide treatment at the 2-leaf stage did not seem to decrease numbers of Hessian fly. Because damage by Hessian fly and frit fly is difficult to distinguish without dissecting the tiller, some of the damage associated with earlier sowings has probably been caused by Hessian fly.

\section{Weeds}

In the Nordic countries Tripleurospermum inodorum, Stellaria media, Viola arvensis, Myosotis arvensis are common dicotyledonous winter-annual weed species of winter cereals (Raatikainen et al. 1978, Hallgren and Fogelfors 1995, Andreasen et al. 1996). These four weed species and Lamium purpureum were predominant in our experiments, too. Some of the weed species were so few in number that data were pooled in the analysis into the group "others". In contrast to the earlier weed survey in Finland in the early 1970s, we did not have e.g. Ranunculus repens L. or any other peren- nial weeds in our experimental fields. Our experiments were situated in western Finland where the diversity of weed flora is smaller than in eastern Finland (Raatikainen et al. 1985).

The highest weed pressure was in the plots sown earlier than currently recommended. The most abundant weeds in early and normal sowings were T. inodorum, S. media, V. arvensis, M. arvensis and L. purpureum. The great collapse in the total weed density in Mietoinen during the winter $2000 / 2001$ is explained by high mortality of $L$. purpureum, although the species is classified as a winter annual. Likewise, a high proportion of summer annuals in early sowings in Pälkäne explains the greater winter mortality in those plots.

According to Raatikainen and Raatikainen (1979) some weed species are more abundant in early and others in late sowings. Still, they found no statistical evidence that $T$. inodorum, $S$. media, and $V$. arvensis would emerge more in early sowings. This contrasts with our findings.

The maximum weed density was 284 weeds $\mathrm{m}^{-2}$ in Pälkäne in autumn 2000 and the maximum total weed biomass was $83 \mathrm{~kg} \mathrm{ha}^{-1}$ in Jokioinen in spring 2000. In practice, there were no significant differences in the competitive ability of rye varieties to suppress weed growth during winter. As all plots were treated with an effective herbicide after our spring observations, there was no possibility to monitor the competitive ability of rye varieties later in the season.

Weed growth was recorded in early May, about one month earlier than in the weed survey of Raatikainen et al. (1985). In their national survey the total weed density was 303 weeds $\mathrm{m}^{-2}$ (Raatikainen and Raatikainen 1979) and the overall weed biomass was $800 \mathrm{~kg} \mathrm{ha}^{-1}$, which is about ten times higher than the weed biomass in our experiments. It is also possible, that the weed pressure in winter cereal fields has lessened over the decades as Hyvönen et al. (2003) noted in spring cereals.

We established that the ability of weed species to survive the winter varies according to site and year. T. inodorum, S. media, M. arvensis and $L$. purpureum were weak in winter 2000/2001 whereas $V$. arvensis got through the both winters well; its density increasing in most cases between our 
Vol. 15 (2006): 43-60.

autumn and spring assessments. V. arvensis seems to thrive in cereal-dominated crop rotations as it has become more frequent in winter cereals in Sweden (Hallgren 1993) and is the most frequent weed species in spring cereals in Finland (Salonen et al. 2001).

It is evident that not all weeds growing in autumn over-winter as reported for field experiments in the United Kingdom (Storkey et al. 1997). Moreover, the results of our experiments suggest that differences in growing conditions over the winter greatly influence weed mortality under Finnish conditions. The first winter was mild for weeds whereas the second winter was so harsh that even $T$. inodorum could not survive.

The variation in winter mortality of weeds among locations, years and species makes it difficult to determine the need for weed control until spring. Raatikainen and Raatikainen (1979) observed that some spring annual weeds in winter cereal fields did not emergence until spring. However, Köylijärvi (1966) got quite good results against $T$. inodorum with MCPA or mecoprop application in autumn in Finland. Although it is very cheap to control weeds with MCPA (product costs $6 \mathrm{ha}^{-1}$ ) in the autumn, it is more unreliable than spring spraying in terms of efficacy and economy. The common practice to spray herbicides in early spring only is advisable also according to our results on weed mortality over the winter. There are effective herbicides on the Finnish market to control the typical weed species of winter cereals in spring. However, the efficacy of herbicides against different weed species may change over time as shown in Sweden (Hallgren 1993).

\section{Conclusions}

Sowing time was the most important factor affecting abundance of pests and weeds in winter rye. Early sowing usually resulted in the most severe problems and no differences with agricultural relevance between varieties were detected. Differences resulting from location and interactions of components complicated the interpretation of results. Furthermore, weather conditions during the growing season and winter played an important role.

The present paper concentrated on early crop development and effects on yield losses and profitability of rye cultivation were not analysed. According to our results, early sowing of rye is risky. Late sowing of rye is recommended because damage from pests and weeds can be reduced simply by postponing the sowing time. This strategy can be applied in particular to organic production but also in conventional cropping in which there are certain restrictions in pesticide use due to their environmental effects on groundwater areas and areas close to water systems. If rye is sown exceptionally early, i.e. before mid August, crop development should be secured with insecticide and herbicide treatments if necessary.

It should be taken into account that the autumns 1999 and 2000 were exceptionally warm. In colder autumns late sown tillers can be too small and not have enough time to harden. Late sowing can become difficult or not even possible because of rainy weather. New cropping methods, e.g. direct drilling, can ensure success of sowing under conditions in which conventional drilling is not feasible. Furthermore, direct drilling enables late sowing even if the weather turns unfavourable and conventional plough-harrow seedbed preparation cannot be done. However, from an economic point of view, sowing has to be completed by $10 \mathrm{Sep}$ tember (at the latest) to ensure adequate crop cover during winter, which is a condition for receiving EU agri-environmental support.

\footnotetext{
Acknowledgements. The authors acknowledge the coordination of the rye research programme by Dr. Simo Hovinen and biometrician Lauri Jauhiainen for statistical consultation. We also wish to thank the staff of MTT Plant production in Jokioinen and at MTT Research Stations in Mietoinen and Pälkäne for technical assistance in the field experiments. The study was funded by the Ministry of Agriculture and Forestry and MTT Agrifood Research Finland.
} 


\section{References}

Andreasen, C., Stryhn, H. \& Streibig, J.C. 1996. Decline of the flora in Danish arable fields. Journal of Applied Ecology 33: 619-626.

Clements, R.O., Bentley, B.R. \& Jackson, C.A. 1990. Influence of date of sowing on frit-fly damage to newly sown Italian rye grass. Crop Protection 9: 101-104.

Cousens, R. 1988. Misinterpretations of results in weed research through inappropriate use of statistics. Weed Research 28: 281-289.

Emden, H.F. van \& Way, M.J. 1973. Host plants in the population dynamics of insects. In: Emden, H.F. van (ed.). Insect/Plant relationships. Oxford, UK: Blackwell Scientific Publications. p. 181-199.

Gomez, K.A. \& Gomez, A.A. 1984. Statistical procedures for agricultural research. 2nd ed. John Wiley \& Sons, New York. 627 p.

Gumbertz, M.L. \& Brownie, C. 1993. Repeated measures in randomized block and split-plot experiments. Canadian Journal of Forest Research 23: 625-639.

Hald, A.B. 1999. The impact of changing season in which cereals are sown on the diversity of the weed flora in rotational fields in Denmark. Journal of Applied Ecology 36: 24-32.

Hallgren, E. 1993. Förändras ogräsfloran och verkan av ett ogräsmedel (Oxitril 4) med tiden? In: Proceedings 34:e svenska växtskyddskonferensen, Uppsala. Rapporter, Ogräs och ogräsbekämpning. p. 15-38.

Hallgren, E. \& Fogelfors, H. 1995. Vilka är ogräsens "tio i top" i Sverige under olika odlingsförutsättningar? In: Proceedings 36:e svenska växtskyddskonferensen, Uppsala. Jordbruk. p. 89-121.

Hämet-Ahti, L., Suominen, J., Ulvinen, T. \& Uotila, P. 1998. Retkeilykasvio (Field flora of Finland). Finnish Museum of Natural History, Botanical Museum, Helsinki. 656 p.

Huusela-Veistola, E. \& Ketola, J. 2004. Kahukärpäsen torjunta rukiilla. Abstract: Control of frit fly in winter rye. In: Hovinen, S. et al. (eds.). Rukiin jalostuksen ja viljelyn tehostaminen pohjoisilla viljelyalueilla (Increasing efficiency of rye breeding and cultivation in the North). Agrifood Research Reports 48. p. 142-149.

Huusela-Veistola, E. \& Känkänen, H. 2000. Relay intercropping of cereals in Finland: prospects and problems. Aspects of Applied Biology 62: 95-100.

Huusela-Veistola, E., Vasarainen, A. \& Grahn, J. 2001. Hessian fly (Mayetiola destructor Say) damage in relay intercropping of cereals in Finland. IOBC wprs Bulletin 24, 6: 113-118.

Hyvönen, T. Ketoja, E. \& Salonen, J. 2003. Changes in the abundance of weeds in spring cereal fields. Weed Research 43: 348-356.

Jonasson, T. 1991. Breeding for insect resistance in cereals. Journal of the Swedish Seed Association 101: 108-110.

Kanervo V. \& Vappula, N.A. 1965. Crop pests. In: Pessi Y. (ed.). Agriculture in Northern Fennoscandia. Part III. Agricultural research work in Finland. Acta Agriculturae Scandinavica. Supplementum 13: 163-179.

Köylijärvi, J. 1966. Saunakukan torjunta syysruiskutuksin. Koetoiminta ja käytäntö 9: 33.
Kurppa, S. 1990. Occurrence of damage and predicting activity of the frit fly (Oscinella frit) in Finland. Annales Agriculturae Fenniae 29: 39-46.

Laine, A. 2005. Peltokasvien vertailu Varsinais-Suomessa. Tulosten tarkastelua Mietoinen 31.1.2005. p. 23.

Lindblad, M. 1997. Dynamics and forecasting of frit fly populations in Sweden. Doctoral thesis. Acta Universitatis Agriculturae Sueciae. Agraria 40.

Linnomäki, H. 1958. Syysrukiin kylvöaikakokeet Hämeen koeasemalla. Summary: Sowing time trials with winter rye at Häme Experimental station. In: Mukula, J. (ed.). Maatalous ja koetoiminta 12: 147-153.

Littell, R.C., Milliken, G.A., Stroup, W.W. \& Wolfinger, R.D. 1996. SAS system for mixed models. SAS Institute INC, Gary, NC. 633 p.

Mukula, J. \& Rantanen, O. 1989. Climatic risks to the yield and quality of field crops in Finland: III. Winter rye 1969-1986. Annales Agriculturae Fenniae 28: 3-11.

Neter, J., Kutner, M., Nachtsheim C. \& Wasserman, W. 1996. Applied linear statistical models. 4th edition. Irwin, Chicago, USA. $1310 \mathrm{p}$.

Nielsen, L.B. \& Nielsen, B.O. 1984. Oscinella frit (L.) and $O$. pusilla (Mg.) (Diptera, Chloropidae) in agricultural grass in Denmark. Zeitschrift für Angewandte Entomologie 98: 264-275.

Paatela. J. 1953. Tärkeimmät viljalajikkeemme ja niiden viljelyalueet. Summary: The most important varieties of cereal grown in Finland and their growing areas. Acta Agralia Fennica 80, 1. Helsinki. 78 p.

Pessi, Y. 1965. Agriculture in Northern Fennoscandia. Part III. Agricultural research work in Finland. Acta Agriculturae Scandinavica. Supplementum 13. p. 117-124.

Raatikainen, M. \& Raatikainen, T. 1979. Syysrukiin perustaminen, hoito ja rikkaruohojen ekologia. Journal of Scientific Agricultural Society of Finland 51: 432479.

Raatikainen, M., Raatikainen, T. \& Mukula, J. 1978. Weed species frequencies and densities in winter cereals in Finland. Annales Agriculturae Fenniae 17 (Seria Agricultura No. 58): 115-142.

Raatikainen, M, Raatikainen, T. \& Mukula, J. 1985. The species, frequencies and densities in winter cereals in Finland. Annales Agriculturae Fenniae 24: 1-30.

Riggert, E. 1935. Zur Kenntnis der Lebensgewohnheiten von Oscinella frit L. und ihrer Jugenstadien. Arbeiten über Physiologische und Angewandte Entomologie 2, 2: 101-156.

Ryabchenko, N.A. \& Merkushina, A.S. 1994. Specificities of frit fly adaptation to resistant cultivars. Russian Agricultural Sciences 7: 15-17.

Salonen, J., Hyvönen, T. \& Jalli, H. 2001. Weeds in spring cereal fields in Finland - a third survey. Agricultural and Food Science in Finland 10: 347-364.

Serenius, M., Huusela-Veistola, E., Avikainen, H., Pahkala, K. \& Laine, A. 2005. Effects of sowing time on pink snow mould, leaf rust and winter damage in winter rye varieties in Finland. Agricultural and Food Science 14: 362-376. 
Vol. 15 (2006): 43-60.

Sinelnikov, E.A. 1996. Multiple resistance in spring wheat to late-wheat shoot fly Phorbia securis (Dipt. Anthomyiidae) and frit flies Oscinella app (Dipt., Chloropidae). IOBC wprs Bulletin 19: 25-29.

Storkey, J., Cussans, J.P., Lutman, P.J.P. \& Blair, A.M. 1997. The importance of mortality in weed populations between autumn and spring on the reliability of yield loss predictions in winter wheat. In: Brighton Crop Protection Conference, Brighton, England, 17-20 November 1997. Farnham: The British Crop Protection Council. p. 1025-1030.

Tiittanen, K. 1959. Kahukärpäsen viljakasveissa aiheuttamat tuhot Suomessa vuosina 1948-1958. Referat: Schäden durch die Fritfliege (Oscinella frit L., Dipt.) bei Getreide in Finnland in den Jahren 1948-1958. Die
Staatliche Landwirtschaftliche Versuchstätigkeit Veröffentlichung 178: 110-125.

Valle, O. 1958. Kylvöajan merkityksestä syysrukiin ja syysvehnän viljelyssä Etelä-Suomessa. Summary: The influence of sowing time on the cultivation of winter rye and winter wheat in South Finland. In: Mukula, J. (ed.). Maatalous ja koetoiminta 12: 159-176.

Yearbook of Farm Statistics 2003. Information Centre of the Ministry of Agriculture and Forestry, Helsinki, Finland. Official statistics of Finland. Agriculture, forestry and fishery 2003, 62. $266 \mathrm{p}$.

Yearbook of Farm Statistics 2004. Information Centre of the Ministry of Agriculture and Forestry, Helsinki, Finland. Official statistics of Finland. Agriculture, forestry and fishery 2004, 61. $268 \mathrm{p}$.

\title{
SELOSTUS
}

\section{Kylvöajan ja lajikkeen vaikutus rukiin tuhoeläinten ja rikkakasvien esiintymiseen}

\author{
Erja Huusela-Veistola, Heikki Jalli, Jukka Salonen, Katri Pahkala ja Antti Laine \\ Maa- ja elintarviketalouden tutkimuskeskus
}

Rukiin viljelyala Suomessa on vähentynyt 1950-luvun 122000 hehtaarista nykyiseen noin 30700 hehtaariin (v. 2003). Viljelyn vähenemisen syynä on ollut syksyn kylvöolosuhteiden epävakaus ja pitkäkortisten lajikkeiden huono soveltuvuus nykyiseen puintitekniikkaan. Vuonna 1999 alkaneen tutkimushankkeen 'Rukiin jalostuksen ja viljelyn tehostaminen pohjoisilla viljelyalueilla' yhdessä osahankkeessa on keskitytty rukiin uusien lajikkeiden viljelytekniikkaan. Monet rukiin kasvinsuojeluun liittyvät käytännöt ja ohjeet perustuvat 1950-1970-luvuilla tehtyihin tutkimuksiin, vaikka uusien lajikkeiden myötä muuttuva viljelytekniikka vaatii tarkennusta myös lajikkeiden kasvinsuojeluohjeisiin.

Tutkimuksemme tarkoituksena oli selvittää kylvöajan vaikutusta eri ruislajikkeiden alkukehitykseen ja kasvinsuojelutarpeeseen. Tuhohyönteisten kasvitautien ja rikkakasvien esiintymistä tutkittiin sekä syksyllä ennen talvehtimista että aikaisin keväällä. Kasvitaudeista ja talvituhoista tehdyt havainnot raportoidaan erikseen. Tutkimus toteutettiin kenttäkokeena kolmella koepaikalla (Jokioinen, Pälkäne, Mietoinen) kahtena vuonna (1999-2001). Koetekijöinä oli kylvöaika (aikainen kylvö viikolla 32 , normaali kylvö viikolla 34 ja myöhäinen kylvö viikolla 36) ja lajike (suomalainen populaatiolajike Anna, puolalainen lyhytkortinen populaatiolajike Amilo, lyhytkortinen suomalainen linja Bor 7068 ja kaksi saksalaista hybridilajiketta, Esprit vuonna 1999 ja Picasso vuonna 2000).

Kasvintuhoojien runsaus mitattiin kasvukauden päätyttyä lokakuun puolivälissä ja uudelleen kasvukauden alkaessa toukokuun alussa. Kasvinäytteistä laskettiin kahukärpäsen (Oscinella frit) ja hesseninsääsken (Mayetiola destructor) vioittamien kasvien määrä. Samoista kasvinäytteistä mitattiin myös taimien pituus ja kuivapaino. Rikkakasvit laskettiin koeruuduittain kahdelta $0.25 \mathrm{~m}^{2}$ näytealalta. Keväällä mitattiin myös rikkakasvien biomassa. Oraiden ja versojen lukumäärä laskettiin kahden rivimetrin matkalta ruuduittain lokakuussa.

Rukiin taimettuminen aikaisin kylvetyissä ruuduissa oli epätasaisempaa syksyllä 1999 kuin 2000. Molempina vuosina myöhään kylvetyt kasvustot taimettuivat parhaiten. Syksyllä 1999 taimettumisessa ei havaittu eroa lajikkeiden välillä, mutta vuonna 2000 Picasso-kasvusto oli tiheintä. Sekä kylvöaika että lajike vaikuttivat versojen määrään neliömetrillä syksyllä. Syksyllä 1999 kahukärpäsvioitus vähensi aikaisin kylvetyn kasvuston versotiheyttä Pälkäneellä. Syksyllä 1999 Espritin versotiheys oli Annaa ja Bor 7068:aa suurempi, vuonna 2000 Picassolla oli suurin versotiheys. Molempina vuosina lokakuussa suurimmat rukiin taimet olivat Pälkäneellä ja pienimmät Jokioisissa. Lisäksi kylvöajalla oli selvä 
Huusela-Veistola, E. et al. Sowing time affects abundance of pests and weeds in rye

vaikutus taimien kokoon: Mitä aikaisemmin kylvetyt kasvustot, sitä suuremmat taimet. Vuonna 1999 ei lajikkeiden välillä havaittu eroa taimien kuivapainossa, mutta syksyllä 2000 Annan taimet olivat muita kookkaampia.

Kylvöajalla oli erittäin merkitsevä vaikutus rukiin kasvintuhoojien määrään. Tuhoeläinongelmat (kahukärpänen, hesseninsääski) keskittyivät aikaisin kylvettyihin kasvustoihin. Kahukärpästuhoja oli jonkin verran myös normaaliin aikaan kylvetyssä rukiissa, etenkin Pälkäneellä, missä ruis taimettui nopeammin kuin muilla koepaikoilla. Myöhään kylvetyissä kasvustoissa kahukärpäsvioitusta oli erittäin vähän. Lajikkeiden välisiä eroja kahukärpäsmäärissä ei käytännöllisesti katsoen ollut. Aikaisin kylvetyissä kasvustoissa rukiin taimettumisvaihe on todennäköisemmin samaan aikaan kahukärpäsen lento- ja muninta-ajankohdan kanssa. Lisäksi lämmin ja aurinkoinen sää rukiin taimettumisvaiheessa lisää kahukärpäsvahinkojen todennäköisyyttä. Aikaisin kylvetyn rukiin kahukärpästuhoja voidaan vähentää tekemällä kemiallinen torjunta rukiin 2-lehtivaiheessa.

Rikkakasveja oli eniten (lukumääräisesti ja biomassana mitattuna) aikaisin kylvetyissä kasvustoissa ja vähiten myöhään kylvetyissä kasvustoissa muutamaa poikkeusta lukuun ottamatta. Ruislajikkeiden väliset erot rikkakasvimäärissä jäivät vähäisiksi. Kenttäkokeiden rikkakasvilajisto ja lajien talvehtiminen vaihtelivat koepaikoittain ja vuosittain. Rikkakasvilajisto oli pääosin samanlainen kuin aiemmissa tutkimuksissa, mutta monivuotisia rikkakasveja ei esiintynyt. Rikkakasvien talvehtimiseroista johtuen, rikkakasvien kemiallinen torjunta kannattaa tehdä vasta keväällä.

Rukiin aikainen kylvö lisää kasvinsuojeluongelmia, jotka vaikuttavat olennaisesti kasvuston alkukehitykseen. Jos näitä ongelmia halutaan vähentää, ei ruista kannata kylvää liian aikaisin, vaan aikaisintaan elokuun loppupuolella. Kylvön viivyttäminen on suositeltavaa etenkin luomuviljelyssä. Vaikka tutkimuksessamme rukiin myöhäinen kylvö oli tehokas tapa vähentää kahukärpäsistä ja rikkakasveista aiheutuvia haittoja, on otettava huomioon, että koevuosien syksyt olivat poikkeuksellisen lämpimät ja suotuisat kylvön viivästyttämiselle. Kaikkina vuosina myöhään kylvetty ruis ei välttämättä ehdi kehittyä tarpeeksi pitkälle ja karaistua ennen talventuloa, minkä seurauksena talvehtiminen ja keväinen kasvuun lähtö voi heiketä. Lisäksi myöhäinen kylvö voi vaikeutua tai jopa estyä sateiden vuoksi. Uudet viljelymenetelmät, kuten suorakylvö, voivat kuitenkin mahdollistaa kylvön sellaisissa olosuhteissa, joissa kylvö tavanomaisilla menetelmillä ei onnistu. 